\title{
Communities of circles
}

\author{
Richard Ennals $\cdot$ David Hutchins
}

Published online: 19 January 2012

(C) Springer-Verlag London Limited 2012

The two editors have jointly been involved since 2005 in the series of conventions and international dialogues which have resulted in this special issue.

We had both been involved in the Quality movement in industry and shared our frustration at developments, as in the UK the focus was increasingly on Compliance rather than Empowerment. An overwhelmingly top-down process tended to stifle innovation and creativity by individual workers, rather than empowering them to bring about continuous improvement.

The first sign of change did not come from the UK or USA, but from Asia. Japan had been the birthplace of Quality Circles, and India hosted their adaptation for schools, with Students' Quality Circles.

It was not possible to visit City Montessori School in Lucknow, India, without being overwhelmed by the energy and enthusiasm of Circles of young people, tackling practical problems, and giving case study presentations of professional standard. With the founder manager Jagdish Gandhi taking a visionary lead, there is an atmosphere that is not so much Hollywood or Bollywood, but "Qualiwood": scale, colour, energy, enthusiasm, discipline, choreography: unforgettable.

The editors faced the challenge of going from national and international conventions, to produce a truly international set

\footnotetext{
R. Ennals $(\bowtie)$

Department of Corporate Responsibility and Working Life, Kingston Business School, Kingston University, Kingston Hill, Kingston KT2 7LB, UK

e-mail: richard.ennals@gmail.com

D. Hutchins

Kingston Business School, Kingston University, Kingston Hill, Kingston KT2 7LB, UK

e-mail: david@hutchins.co.uk
}

of articles which can provide a shared resource for ongoing staff development and building of a global movement.

At conventions we tend to find twin agendas for student participants and staff advisors. As the movement has grown, the need for development, dialogue and reflection has steadily increased.

The resulting collection of articles is the outcome of a truly international "Community of Circles". The directors generals of the national chapters of the World Council for Total Quality and Excellence in Education (WCTQEE) are in almost daily contact, as they recognise how much they have to learn from each other. We see the launch of bilateral projects, often bringing together national groups with histories of tension.

The Students' Quality Circle movement has used the English language, but with approaches to education and work organisation which come from many other countries around the world. We have become accustomed to fluent performances by students from the age of 8 . They represent our future.

Older members of the WCTQEE Board have come to recognise that we are a Senior Quality Circle. We share our experiences and insights and hope to be of use to our younger colleagues and students.

In SQCs, young people of all ages are able to talk about a world at peace, where people of different religions can live and work together, and where a problem shared and tackled can be a problem solved. This is practical collaboration, creating collaborative advantage.

The SQC movement has significance beyond education. It offers a human-centred alternative to the dead hand of Taylorism. It provides a route to empowerment in the new global knowledge society. In a world of problems and divisions, we have a movement in many countries which knows that sustainable solutions can be found. It is not 
something we can do by ourselves as individuals: "Together we can".

In Higher Education, students who engage through SQCs can change the way in which their universities work. They can take the lead in building partnership for the new organisation of academic work. Having developed such ways of working, they can go on to transform working life.

The stakes are high. We hope that this special issue helps to build a sustainable movement in difficult times.

The articles are of varying lengths, as we have tried to create an international picture which accommodates many perspectives. Each country has a distinctive story to tell, but it is apparent that much can be learned from the different experiences of others.

Circles are building blocks for a bottom-up process of change. At our national and international conventions, members are empowered to see themselves as leaders. The movement can spread. At present, there are 25 national chapters, but as links continue to develop with UNESCO, we hope to see significant expansion. 